\title{
A Pharmacokinetic Model for Radioimmunotherapy Delivered Through Cerebrospinal Fluid for the Treatment of Leptomeningeal Metastases
}

\author{
Yonggang Lv ${ }^{1}$, Nai-Kong V. Cheung ${ }^{2}$, and Bingmei M. Fu' \\ ${ }^{1}$ Department of Biomedical Engineering, The City College of New York, New York, New York; and ${ }^{2}$ Department of Pediatrics, \\ Memorial Sloan-Kettering Cancer Center, New York, New York
}

Radioimmunotherapy can effectively treat leptomeningeal metastases when radiolabeled antibodies are administered into the cerebrospinal fluid (CSF). We developed a pharmacokinetic model to evaluate the role of kinetic and transport parameters of radioimmunotherapy in maximizing the therapeutic ratio, the ratio of the area under the curve for the concentration of the bound antibodies versus time (AUC[ $\left.\left.\mathrm{C}_{\mathrm{IAR}}\right]\right)$, to that for unbound antibodies $\left(A \cup C\left[C_{I A}\right]\right)$. Methods: We simplified the CSF space as a single compartment and considered the binding of antibodies to antigens on tumor cells lining the surface of the CSF space. Mass conservation was applied to set up the equations for $\mathrm{C}_{\mathrm{IAR}}, \mathrm{C}_{\mathrm{IA}}$, and other pharmacokinetic variables. A RungeKutta method was used to solve the equations. Results: This model agreed with the measured data in 10 of 14 patients in the phase I trial of intra-Ommaya radioimmunotherapy using ${ }^{131}$ I-3F8. Using this model, we predicted that increasing the affinity of antibodies to antigens greatly increases $A U C\left(C_{I A R}\right)$ but not $A \cup C\left(C_{I A}\right)$; for the same amount of isotope administered, the smaller antibody dose and the higher specific activity improves therapeutic ratio. When the isotope half-life $\left(t_{1 / 2-1}\right)$ was $0.77 \mathrm{~h}$, increasing the antibody association constant enhanced $A U C\left(\mathrm{C}_{\mathrm{IAR}}\right)$ much more than did decreasing the dissociation constant, even if overall affinity was unchanged. When $t_{1 / 2-1}$ reached $240 h$, decreasing the dissociation constant would slightly enhance $\mathrm{AUC}\left(\mathrm{C}_{\mathrm{IAR}}\right)$. Other predictions were that decreasing the CSF bulk flow rate would increase $A U C\left(C_{I A R}\right)$, with $3 \mathrm{~mL} / \mathrm{h}$ being optimal; at the same amount of antibody administered by continuous infusion and by split administrations, compared with that by the single bolus administration, one could improve $A U C\left(\mathrm{C}_{\mathrm{IAR}}\right)$ by up to 1.8- and 1.7-fold, respectively; and for an antibody affinity of $10^{-8} \mathrm{M}$, increasing $\mathrm{t}_{1 / 2-1}$ from 0.77 up to $64 \mathrm{~h}$ could greatly enhance the therapeutic ratio. Conclusion: The strong agreement between model predictions and patient data supports the validity of the assumptions and simplifications in our model. The predictions using this model are not intuitive and need to be validated in future clinical trials. The improved therapeutic ratio by optimized kinetic and transport parameters may enhance the clinical efficacy of this new treatment modality.

Received Dec. 1, 2008; revision accepted May 4, 2009.

For correspondence or reprints contact: Bingmei M. Fu, The City College of New York, 138th St. at Convent Ave., T-402, New York, NY 10031.

E-mail: fu@ccny.cuny.edu

COPYRIGHT ๑) 2009 by the Society of Nuclear Medicine, Inc.
Key Words: kinetic model; radioimmunotherapy; intraventricular administration; cerebrospinal fluid; ${ }^{131}$ I-3F8

J Nucl Med 2009; 50:1324-1331

DOI: 10.2967/jnumed.108.060798

$\mathbf{T}$ umor cells can invade the cerebrospinal fluid (CSF) and disseminate throughout the neuroaxis by the constant flow of CSF, which travels from the ventricles to the spinal canal and over the cortical convexities. The involvement of the leptomeninges by any cancer is a serious complication with significant morbidity and mortality (1-3). Its frequency is increasing as patients live longer and as neuroimaging modalities improve, approaching 5\% in solid tumors such as breast cancer and lung cancer (2). Leptomeninges disease is most common in patients with disseminated systemic disease $(4,5)$ and is the initial manifestation in $5 \%-10 \%$ of patients (6). Concurrent parenchymal brain metastases are not uncommon $(11 \%-31 \%$ of patients) $(5,7)$. Historically, the incidence of leptomeninges metastasis was often underestimated because tumors were not apparent to gross inspection at autopsy and because leptomeninges seeding could be focal (e.g., spinal only) (8), microscopic, and clinically subtle (9).

Neuroblastoma is the most common extracranial tumor of the sympathetic nervous system, occurring predominantly in early childhood and accounting for $6.7 \%$ of childhood cancer. With increasing periods of remission, CNS metastasis (both parenchymal and leptomeninges) - though rare formerly (10) - has substantially increased in the past decade. Antibody-based radioimmunotherapy administered through the CSF has clinical potential in the treatment of cancers metastatic to the leptomeninges or brain. ${ }^{131}$ I-labeled monoclonal antibodies (mAbs) targeting GD2 (e.g., mAb 3F8) or B7H3 (e.g., mAb 8H9), when administered through an Ommaya reservoir, have proven safe in phase I clinical trials (11). Patients with relapsed neuroblastoma in the CNS (brain or leptomeninges), when treated with salvage regimens 
containing either intra-Ommaya ${ }^{131} \mathrm{I}-3 \mathrm{~F} 8$ or ${ }^{131} \mathrm{I}-8 \mathrm{H} 9$, have survived for extended periods. Given the unique physiology of the CSF compartment and the well-defined kinetic or radiochemical properties of mAbs, radioimmunotherapy delivered through the CSF can be optimized.

The CSF is secreted mainly by the choroid plexus in the walls of the lateral ventricles and flows constantly and unidirectionally from the lateral ventricles through the interventricular foramina into the third then fourth ventricles, and finally into subarachnoid space before draining into lymphatics and veins (12). Although the barrier between the blood and the normal brain tissue is tight, antibodies can penetrate abnormal tumor vessels and enter into tumor tissue, even when it is in the brain. In addition, even though antibody penetration into CSF is hampered by tight junctions in the bloodCSF barrier (13), the transfer of antibodies between the CSF in the subarachnoid space and the meninges and in the ependyma-lined lateral ventricles (brain-CSF interface) is relatively free (12). Because of these unique features, CSF is highly suitable for radioimmunotherapy on metastatic tumors to the leptomeninges. CSF compartmental radioimmunotherapy (cRIT) avoids systemic toxicity (e.g., myelosuppression) and neutralization of radiolabeled $\mathrm{mAb}$ by human serum antibodies.

Although radioimmunotherapy through CSF administration has been used to treat metastatic tumors to the CNS (1416), a quantitative pharmacokinetic model is unavailable to predict the optimal conditions for radioimmunotherapy delivered through the CSF. Over the last few decades, a series of models has been developed for the distribution of antibodies in humans and other animals (17-19). Unfortunately, all of these models considered only intravenous administration and did not take account of the effect of isotope decay.

An optimization model will help explain the complex dynamics of antibody and radiation dose delivered to tumor cells and to the normal brain and provide a tool to define the critical parameters to improve effectiveness and safety of ${ }^{131} \mathrm{I}-\mathrm{mAb}$ radioimmunotherapy administered through the CSF. In addition, because different isotopes have distinct microdosimetric properties, their biologic effect in CSF radioimmunotherapy can be simulated and compared. These critical parameters of CSF dynamics and mAb pharmacokinetics can be manipulated by pharmacologic interventions and genetic engineering, respectively, and be tested in vivo using rats or mice with leptomeninges xenografts. The longterm plan is to bring these concepts to human phase I and II studies.

cRIT using radioiodinated mAbs administered intrathecally results in favorable $\mathrm{CSF}$-to-blood activity concentrations and radiation dose ratios and may be useful in the treatment of leptomeninges disease (20-22). For example, cRIT using ${ }^{131}$ I-labeled murine antitenascin mAbs in patients with malignant glioma was feasible and well tolerated and improved survival (23-26).

We now report a pharmacokinetic model for the intraventricular (intra-Ommaya) administration of radiolabeled an- tibodies. As a first validation, we note that model predictions agreed almost perfectly with patient pharmacokinetic data from a phase I clinical study in which patients with metastatic neuroblastoma were treated with CSF radioimmunotherapy (11). For optimization of CSF radioimmunotherapy, we define thetherapeutic ratio by dividing the area under the curve for CSF concentration versus time of the bound antibodies by that for the unbound antibodies. This model was used to evaluate the role of antibody association or dissociation rate constants, the antigen concentration, the specific activity of radiolabeled antibody, the dose of injected antibodies, the administration schedule, the half-life of the isotope, and the CSF bulk flow rate $\left(\mathrm{CL}_{\mathrm{CSF}}\right)$.

\section{MATERIALS AND METHODS}

\section{Pharmacokinetic Model for the CSF Delivery}

Figure 1 describes our model for the radioimmunotherapy through CSF administration. Because few free-floating tumor cells are found in the CSF (11), they are assumed to be attached to the surface of the CSF space, next to the arachnoid and the surface of either the brain or the spinal cord. Antibodies loaded with radioactive isotopes are administered intraventricularly and carried by the CSF flow to the entire CSF surface space. Usually these antibodies are macromolecules that do not travel across the tight junctions between the brain endothelial cells and choroid plexus epithelial cells, which form the blood-brain and blood-CSF barriers $(12,13)$. Previous studies also showed that most antibodies used in radioimmunotherapies do not penetrate more than a few millimeters $\left(10^{-3} \mathrm{~m}\right)$ from the CSF into the brain tissue $(27,28)$. Therefore, the binding of antibodies to tumor cells occurs only at the surface of the CSF space or at the brain-CSF interface. On the basis of these observations and assumptions, we developed a pharmacokinetic model for radioimmunotherapy through CSF administration (sup-

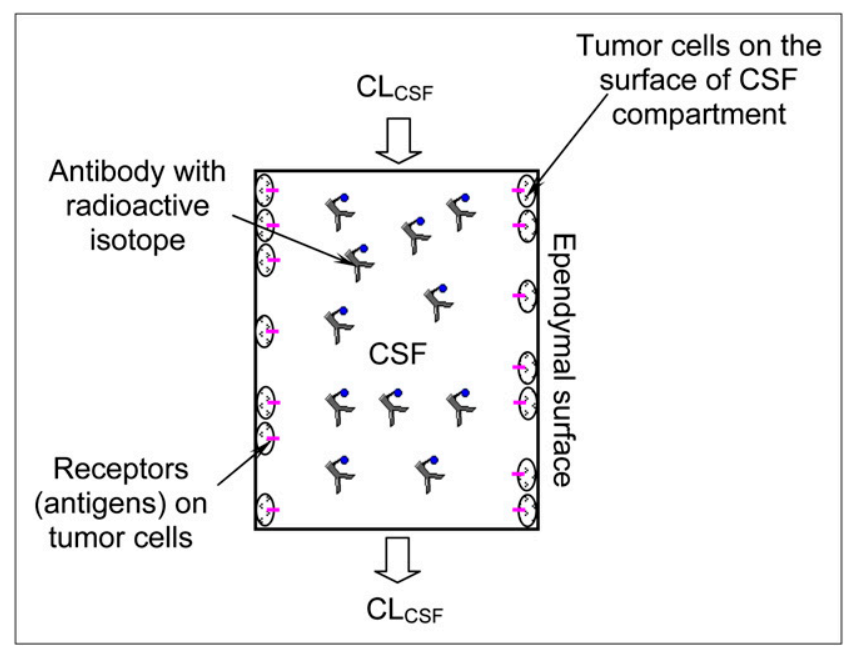

FIGURE 1. Schematic of our pharmacokinetic model for radioimmunotherapy through CSF administration. CSF space was simplified as compartment of volume $V$ with surface area S. Radioactive isotope-loaded antibodies are injected into CSF space and assumed to be well mixed immediately. Binding of antibodies to receptors (antigens) on tumor cells occurs at surface of CSF compartment. 
plemental materials, which are available online only at http:// jnm.snmjournals.org).

\section{Therapeutic Ratio and Optimization Criteria}

The therapeutic amount of radioactive isotope-loaded antibodies is determined by the time-dependent quantity of radioactivity on bound antibodies to the antigens on tumor cells $\left(\mathrm{C}_{\text {IAR }}\right)$. This amount can be represented by the area under the $\mathrm{C}_{\mathrm{IAR}}$-versus-time curve, which is denoted as $\mathrm{AUC}\left(\mathrm{C}_{\mathrm{IAR}}\right)$. The larger the $\mathrm{AUC}\left(\mathrm{C}_{\mathrm{IAR}}\right)$, the bigger the radiation dose to tumor cells and the bigger the cytotoxic effect. While maximizing $\mathrm{AUC}\left(\mathrm{C}_{\mathrm{IAR}}\right)$ to achieve therapeutic effects, the goal was to minimize bystander damage from radioactivity on free antibodies $\left(\mathrm{C}_{\mathrm{IA}}\right)$ in the CSF. This reduction of damage can be achieved if the area under the $\mathrm{C}_{\mathrm{IA}}$-versus-time curve $\mathrm{AUC}\left(\mathrm{C}_{\mathrm{IA}}\right)$ is minimized or the ratio of $\mathrm{AUC}\left(\mathrm{C}_{\mathrm{IAR}}\right)$ to $\mathrm{AUC}\left(\mathrm{C}_{\mathrm{IA}}\right)$ is maximized.

Mathematically, after obtaining $\mathrm{C}_{\mathrm{IAR}}(\mathrm{t})$ and $\mathrm{C}_{\mathrm{IA}}(\mathrm{t})$ by the numeric method described in the supplemental materials, we calculated $\mathrm{AUC}\left(\mathrm{C}_{\mathrm{IAR}}\right)$ and $\mathrm{AUC}\left(\mathrm{C}_{\mathrm{IA}}\right)$ by the following integrations,

$$
\operatorname{AUC}\left(\mathrm{C}_{\mathrm{IAR}}\right)=\int_{0}^{\infty} \mathrm{C}_{\mathrm{IAR}}(\mathrm{t}) \mathrm{dt} \text {, and } \operatorname{AUC}\left(\mathrm{C}_{\mathrm{IA}}\right)=\int_{0}^{\infty} \mathrm{C}_{\mathrm{IA}}(\mathrm{t}) \mathrm{dt}
$$

$\mathrm{AUC}\left(\mathrm{C}_{\mathrm{IAR}}\right)$ and $\mathrm{AUC}\left(\mathrm{C}_{\mathrm{IA}}\right)$ depend on the association and dissociation rate constants ( $\mathrm{k}_{\mathrm{AR}}$ and $\mathrm{k}_{-\mathrm{AR}}$, respectively) or the affinity of the antibody to the antigen $\mathrm{K}_{\mathrm{d}}=\frac{\mathrm{k}_{-\mathrm{AR}}}{\mathrm{k}_{\mathrm{AR}}}$, dose of the antibody administered, antibody administration schedules, tumor antigen concentrations, specific activity of the isotope, isotope half-life $\left(\mathrm{t}_{1 / 2-\mathrm{I}}\right)$, and $\mathrm{CL}_{\mathrm{CSF}}$.

\section{Time-Activity Registration}

Injections of the ${ }^{131}$ I antibody were followed by pharmacokinetic studies in the CSF and blood, in compliance with the institutional review board and hospital guidelines. These procedures were performed after informed written consent for all treatments was received from guardians who understood the potential side effects of each agent and the possibility of unforeseen toxicities. CSF samples were obtained before infusion and at 5, 10, and $30 \mathrm{~min}$ and approximately $1,2,5,24$, and $48 \mathrm{~h}$ after infusion. CSF $(10 \mu \mathrm{L})$ was counted in a well scintillation counter (LKB; Wallac) alongside a ${ }^{131} \mathrm{I}$ standard. Counts per minute were entered into Excel (Microsoft) and converted to activity per gram decay-corrected to the time of administration of the dose.

\section{Antibody Labeling}

Antibodies were initially labeled with the chloramine-T method (29). Excess chloramine-T was neutralized with a 2 molar excess of sodium metabisulphite before antibody purification using a G-25 Sepharose and an anion-exchange column (GE Healthcare). Iodine was greater than $95 \%$ bound by tricarboxylic acid, and immunoreactivity was always greater than $50 \%$ by radioimmunoassay on GD2 glycolipid. The iodination method was subsequently changed to the IODO-GEN method (Pierce), in which antibody was reacted with solid-phase IODO-GEN before purification by G-25 Sepharose and anion exchange, to avoid soluble chemicals. Iodine remained greater than $95 \%$ bound by tricarboxylic acid, and immunoreactivity was always greater than $50 \%$ by radioimmunoassay on GD2 glycolipid.

\section{Parameter Values}

The CSF volume (V) was $140 \mathrm{~mL}$, and its bulk flow rate $\left(\mathrm{CL}_{\mathrm{CSF}}\right)$ was $20 \mathrm{~mL} / \mathrm{h}(12,30)$. The surface area of the CSF space (S) was at least $1,800 \mathrm{~cm}^{2}(27,31)$. The radioactive isotope used in the clinical trial, ${ }^{131} \mathrm{I}$, had a half-life of $193 \mathrm{~h}$ (32). The specific activity of the ${ }^{131} \mathrm{I}-3 \mathrm{~F} 8$ was $185-370 \mathrm{MBq} / \mathrm{mg}$, and the dose injected was $370-1,480 \mathrm{MBq}(11)$. The ranges of the $\mathrm{k}_{\mathrm{AR}}$ and $\mathrm{k}_{-\mathrm{AR}}$ for $3 \mathrm{~F} 8$ to GD2 were $3 \times 10^{3} \mathrm{M}^{-1} \mathrm{~s}^{-1} \leq \mathrm{k}_{\mathrm{AR}} \leq 3 \times 10^{5} \mathrm{M}^{-1} \mathrm{~s}^{-1}$ and $3 \times 10^{-5} \mathrm{~s}^{-1} \leq \mathrm{k}_{-\mathrm{AR}} \leq 3 \times 10^{-3} \mathrm{~s}^{-1}$, respectively (33). All the above values are summarized in Supplemental Table 1.

For the neuroblastoma, the antigen GD2 density per cell, $\mathrm{N}_{\mathrm{R}}$, was approximately $10^{5}-10^{7}(34)$. The tumor cell density at the surface of the CSF space $\left(\mathrm{C}_{\mathrm{SC}}=\frac{1}{\frac{4}{3} \pi\left(\frac{\mathrm{D}_{\mathrm{T}}}{2}\right)^{3}}\right)$ was estimated as 1.91 $\times 10^{9}$ cells $/ \mathrm{mL}$ if the tumor cell diameter $\mathrm{D}_{\mathrm{T}}$ was $10 \mu \mathrm{m}$ and the surface of the CSF space was completely covered by 1 layer of tumor cells. If assuming other coverage percentages (f), the tumor antigen concentration $\left(\mathrm{C}_{\mathrm{R} 0}=\mathrm{f} \times \mathrm{C}_{\mathrm{SC}} \times \mathrm{N}_{\mathrm{R}}\right)$ was estimated from $10^{11}$ to $10^{14}$ antigens $/ \mathrm{mL}$. The estimation for the $\mathrm{C}_{\mathrm{R} 0}$ is detailed in Supplemental Table 2.

\section{RESULTS}

\section{Agreement Between Model Predictions and Patient Data}

To validate our kinetic model for radioimmunotherapy through CSF delivery, we compared the model predictions with the clinical data obtained in the phase I clinical trial (11). In this study, 15 patients (14 completed the trial) received intra-Ommaya delivery of ${ }^{131} \mathrm{I}-3 \mathrm{~F} 8(\sim 370-851 \mathrm{MBq})$. The radioactivity of free antibodies $\mathrm{C}_{\mathrm{IA}}$ in the CSF was measured by serial CSF samplings obtained before infusion and at 5 , 10, and $30 \mathrm{~min}$ and 1, 2, 5, 24, and $48 \mathrm{~h}$ after infusion. Our model predictions fit well with the measured data for $\mathrm{C}_{\mathrm{IA}}$ in 10 of 14 patients, whose $C_{I A}$ values were near the mean of the measured data. The discrepancy existed when the value of $\mathrm{C}_{\mathrm{IA}}$ was too high or too low. Figure 2 shows the agreement of our model predictions for 2 representative patients; the

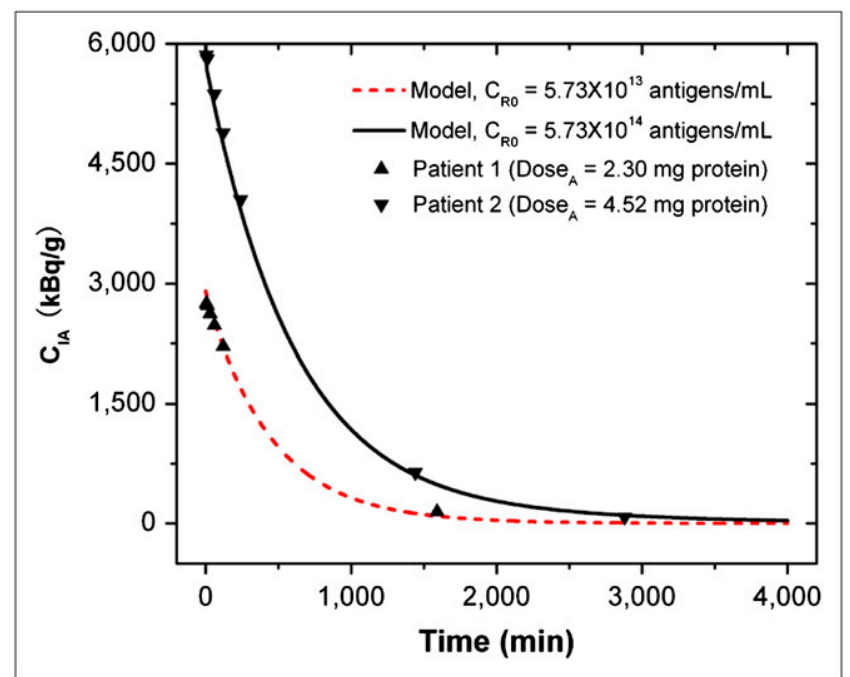

FIGURE 2. Comparison of model predictions and clinical results for time-changing radioactivity of free antibodies $\mathrm{C}_{\mathrm{IA}}$ in CSF compartment. Symbols are clinical results for 2 representative patients, and curves are model predictions. $\mathrm{C}_{\text {I0 }}$ was $185 \mathrm{MBq} / \mathrm{mg}$-protein, $\mathrm{V}$ was $140 \mathrm{~mL}, \mathrm{CL}_{\mathrm{CSF}}$ was 20 $\mathrm{mL} / \mathrm{h}, \mathrm{K}_{\mathrm{d}}$ was $10^{-8} \mathrm{M}\left(\mathrm{k}_{\mathrm{AR}}=3 \times 10^{4} \mathrm{M}^{-1} \mathrm{~s}^{-1} ; \mathrm{k}_{-\mathrm{AR}}=\right.$ $\left.3 \times 10^{-4} \mathrm{~s}^{-1}\right)$, and $\mathrm{t}_{1 / 2-\mathrm{I}}$ was $193 \mathrm{~h}$. 

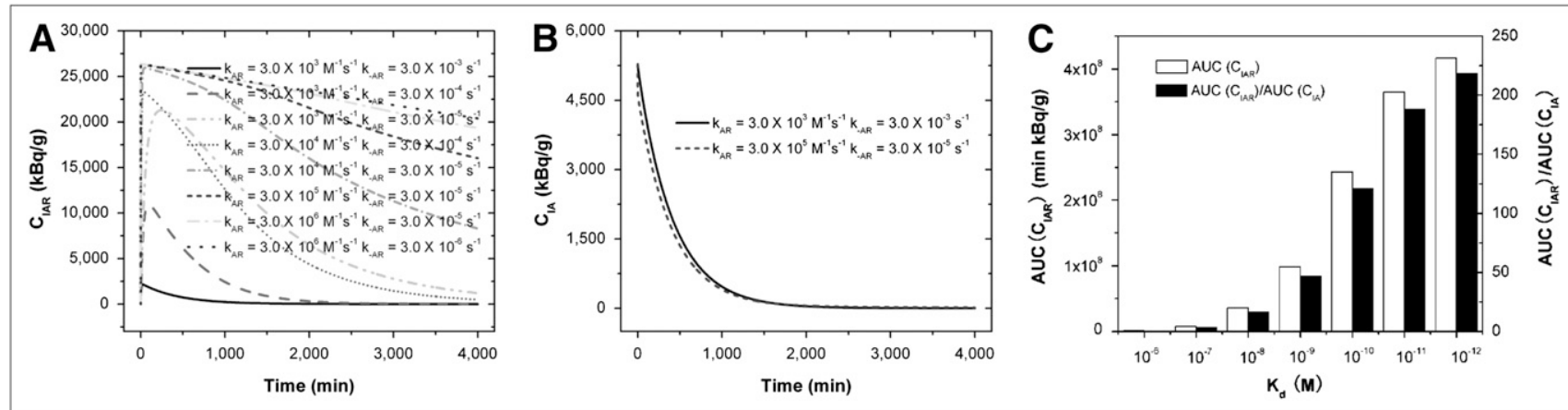

FIGURE 3. Time-changing radioactivity of bound antibodies $C_{I A R}(A)$ and free antibodies $C_{I A}(B)$ as function of $k_{A R}$ and $k_{-A R}$ rate constants of antibodies to antigens. (C) $\mathrm{AUC}\left(\mathrm{C}_{\mathrm{IAR}}\right)$ and $\mathrm{AUC}\left(\mathrm{C}_{\mathrm{IAR}}\right) / \mathrm{AUC}\left(\mathrm{C}_{\mathrm{IA}}\right) . \mathrm{K}_{\mathrm{d}}$ equaled $\frac{\mathrm{k}_{-A R}}{\mathrm{k}_{A R}}$, and $\mathrm{V}$ was $140 \mathrm{~mL}, \mathrm{CL} C S F$ was $20 \mathrm{~mL} / \mathrm{h}$, tumor $\mathrm{C}_{\mathrm{RO}}$ was $5.73 \times 10^{14}$ antigens $/ \mathrm{mL}$, Dose $\mathrm{A}_{\mathrm{A}}$ was $2 \mathrm{mg}, \mathrm{C}_{\mathrm{IO}}$ was $370 \mathrm{MBq} / \mathrm{mg}$, and t $\mathrm{t}_{1 / 2-1}$ was $193 \mathrm{~h}$.

1 patient who received a lower dose may have had a lower tumor antigen concentration, and another who received a higher dose may have had a higher tumor antigen concentration. Supplemental Table 3 summarizes the patient data and model predictions for all 10 patients.

\section{Effect of $k_{A R}$ and $k_{-A R}$ Rate Constants of Antibodies to} Antigens on Therapeutic Ratios

Because the binding of antibodies to antigens plays an important role in the radioactivity of bound antibodies $\left(\mathrm{C}_{\mathrm{IAR}}\right)$ and free antibodies $\left(\mathrm{C}_{\mathrm{IA}}\right)$ in the CSF, we used our model to predict this binding or dissociation effect. The predicted $\mathrm{C}_{\mathrm{IAR}^{-}}$ versus-time and $\mathrm{C}_{\mathrm{IA}}$-versus-time curves under various $\mathrm{k}_{\mathrm{AR}}$ and $\mathrm{k}_{-\mathrm{AR}}$ are shown in Figures $3 \mathrm{~A}$ and $3 \mathrm{~B}$. In Figure $3 \mathrm{~A}, \mathrm{C}_{\mathrm{IAR}}$ increases transiently to a peak after the bolus infusion and decays gradually. The peak value and the decay rate depend on

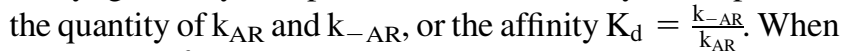
$\mathrm{K}_{\mathrm{d}}$ was $10^{-6} \mathrm{M}$, the peak value of $\mathrm{C}_{\mathrm{IAR}}$ was low and $\mathrm{C}_{\mathrm{IAR}}$ decayed rapidly and reached equilibrium in approximately $500 \mathrm{~min}$. As the affinity increased, or $\mathrm{K}_{\mathrm{d}}$ decreased, the peak value of $\mathrm{C}_{\mathrm{IAR}}$ increased and the decay rate decreased. Figure $3 \mathrm{~B}$ shows that $\mathrm{C}_{\mathrm{IA}}$ decayed quickly to almost zero in approximately $1,500 \mathrm{~min}$ after infusion. In contrast to $\mathrm{C}_{\mathrm{IAR}}$, the decay rate and the time for reaching equilibrium of $\mathrm{C}_{\mathrm{IA}}$ were almost independent of $\mathrm{K}_{\mathrm{d}}$. For these reasons, the $\mathrm{AUC}\left(\mathrm{C}_{\mathrm{IAR}}\right)$ and the $\operatorname{AUC}\left(\mathrm{C}_{\mathrm{IAR}}\right) / \mathrm{AUC}\left(\mathrm{C}_{\mathrm{IA}}\right)$ increase with the affinity. Figure $3 \mathrm{C}$ summarizes the effect of $\mathrm{K}_{\mathrm{d}}$ on $\mathrm{AUC}\left(\mathrm{C}_{\mathrm{IAR}}\right)$ and $\mathrm{AUC}\left(\mathrm{C}_{\mathrm{IAR}}\right) /$ $\operatorname{AUC}\left(\mathrm{C}_{\mathrm{IA}}\right)$. To optimize the therapeutic effect of the radioimmunotherapy, we wanted to maximize $\operatorname{AUC}\left(\mathrm{C}_{\mathrm{IAR}}\right)$ and $\operatorname{AUC}\left(\mathrm{C}_{\mathrm{IAR}}\right) / \mathrm{AUC}\left(\mathrm{C}_{\mathrm{IA}}\right)$. Increasing the affinity of antibodies to antigens allowed us to achieve this goal. However, improvement was not uniform as $\mathrm{K}_{\mathrm{d}}$ decreased. From $10^{-6}$ to $10^{-7} \mathrm{M}$, the improvement in $\operatorname{AUC}\left(\mathrm{C}_{\mathrm{IAR}}\right)$ and $\mathrm{AUC}\left(\mathrm{C}_{\mathrm{IAR}}\right) /$ $\operatorname{AUC}\left(\mathrm{C}_{\mathrm{IA}}\right)$ was 7.6-fold. The improvement reduced to 4.8-, 2.7-, 2.4-, 1.5-, and 1.1-fold, respectively, as $\mathrm{K}_{\mathrm{d}}$ decreased from $10^{-7}$ to $10^{-8} \mathrm{M}, 10^{-8}$ to $10^{-9} \mathrm{M}, 10^{-9}$ to $10^{-10} \mathrm{M}$, $10^{-10}$ to $10^{-11} \mathrm{M}$, and $10^{-11}$ to $10^{-12} \mathrm{M}$.

\section{Effect of $\mathrm{CL}_{\mathrm{CSF}}$ on Therapeutic Ratio}

$\mathrm{CL}_{\mathrm{CSF}}$ may change because of brain disorders (30) and can be reduced using pharmacologic inhibitors (35-38). The influence of $\mathrm{CL}_{\mathrm{CSF}}$ on $\mathrm{AUC}\left(\mathrm{C}_{\mathrm{IAR}}\right)$ and $\mathrm{AUC}\left(\mathrm{C}_{\mathrm{IAR}}\right) / \mathrm{AUC}\left(\mathrm{C}_{\mathrm{IA}}\right)$ predicted by our model is shown in Figure 4. Reducing $\mathrm{CL}_{\mathrm{CSF}}$ increases $\mathrm{AUC}\left(\mathrm{C}_{\mathrm{IAR}}\right)$ and improves the therapeutic effect. However, reducing $\mathrm{CL}_{\mathrm{CSF}}$ decreases $\mathrm{AUC}\left(\mathrm{C}_{\mathrm{IAR}}\right) / \mathrm{AUC}\left(\mathrm{C}_{\mathrm{IA}}\right)$ by increasing more in $\operatorname{AUC}\left(C_{I A}\right)$. This may induce more toxicity in normal tissues. Fortunately, the decreasing rate of $\operatorname{AUC}\left(\mathrm{C}_{\mathrm{IAR}}\right) / \mathrm{AUC}\left(\mathrm{C}_{\mathrm{IA}}\right)$ was slow, less than $3 \% /(\mathrm{mL} / \mathrm{h})$ when $\mathrm{CL}_{\mathrm{CSF}}$ decreased from 20 to $3 \mathrm{~mL} / \mathrm{h}$, whereas the increasing rate of $\mathrm{AUC}\left(\mathrm{C}_{\mathrm{IAR}}\right)$ varied, from $8.7 \% /(\mathrm{mL} / \mathrm{h})\left(\mathrm{CL}_{\mathrm{CSF}}\right.$ from 20 to $10 \mathrm{~mL} / \mathrm{h})$ to $23.5 \% /(\mathrm{mL} / \mathrm{h})\left(\mathrm{CL}_{\mathrm{CSF}}\right.$ from 5 to $\left.3 \mathrm{~mL} / \mathrm{h}\right)$. When $\mathrm{CL}_{\mathrm{CSF}}$ was from 3 to $0 \mathrm{~mL} / \mathrm{h}$, although the increasing rate of $\mathrm{AUC}\left(\mathrm{C}_{\mathrm{IAR}}\right)$ was as high as $55.7 \% /(\mathrm{mL} / \mathrm{h})$, the decreasing rate for $\mathrm{AUC}\left(\mathrm{C}_{\mathrm{IAR}}\right) / \mathrm{AUC}\left(\mathrm{C}_{\mathrm{IA}}\right)$ droped sharply to $47.0 \% /(\mathrm{mL} / \mathrm{h})$.

Effect of Specific Activity $\left(C_{10}\right)$, Antibody Dose (Dose $\left.{ }_{A}\right)$, and Antigen Concentration $\left(\mathrm{C}_{\mathrm{RO}}\right)$ on Therapeutic Ratio

Figure 5 shows the model predictions for $\mathrm{AUC}\left(\mathrm{C}_{\mathrm{IAR}}\right)$ and $\operatorname{AUC}\left(C_{I A R}\right) / A U C\left(C_{I A}\right)$ as a function of injected Dose ${ }_{A}$,

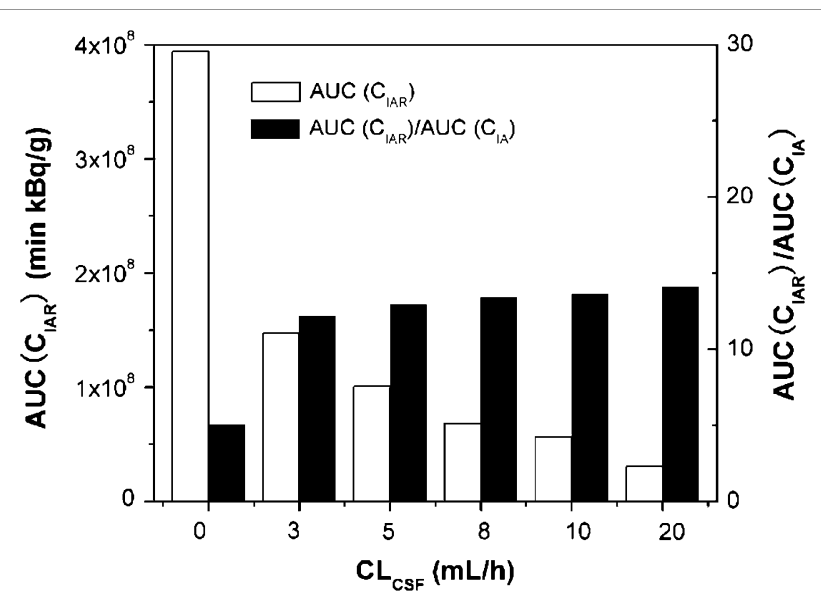

FIGURE 4. $A U C\left(\mathrm{C}_{\mathrm{IAR}}\right)$ and $\mathrm{AUC}\left(\mathrm{C}_{\mathrm{IAR}}\right) / \mathrm{AUC}\left(\mathrm{C}_{\mathrm{IA}}\right)$ as function of $\mathrm{CL}_{\text {CSF. }} \mathrm{V}$ was $140 \mathrm{~mL}, \mathrm{~K}_{\mathrm{d}}$ was $10^{-8} \mathrm{M}\left(\mathrm{k}_{\mathrm{AR}}=\right.$ $\left.3 \times 10^{4} \mathrm{M}^{-1} \mathrm{~s}^{-1} ; \mathrm{k}_{-\mathrm{AR}}=3 \times 10^{-4} \mathrm{~s}^{-1}\right)$, tumor $\mathrm{C}_{\mathrm{RO}}$ was $5.73 \times$ $10^{14}$ antigens $/ \mathrm{mL}$, Dose $\mathrm{A}_{\mathrm{A}}$ was $2 \mathrm{mg}, \mathrm{C}_{\mathrm{IO}}$ was $370 \mathrm{MBq} / \mathrm{mg}$, and $t_{1 / 2-I}$ was $193 \mathrm{~h}$. 


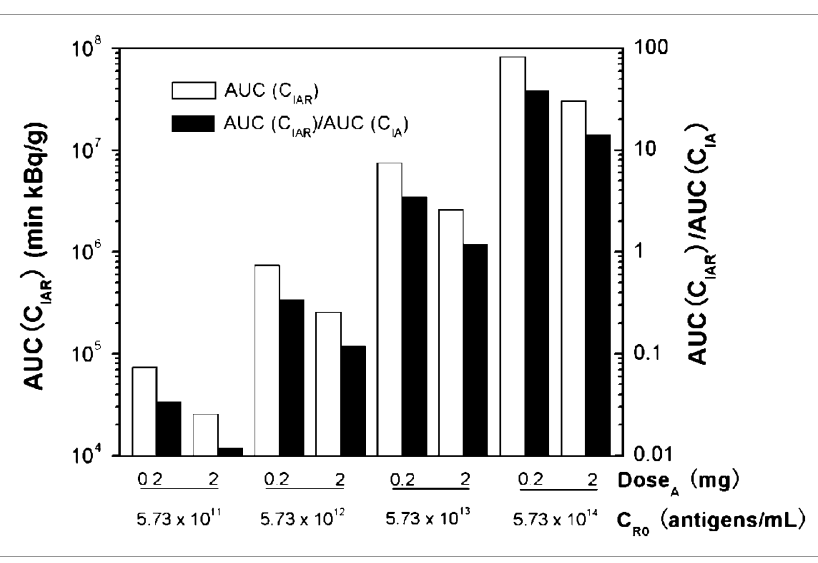

FIGURE 5. $A \cup C\left(C_{I A R}\right)$ and $A \cup C\left(C_{I A R}\right) / A \cup C\left(C_{I A}\right)$ as function of injected Dose ${ }_{A}, C_{I 0}$, and initial $C_{R 0}$. $C_{I 0}$ was $370 \mathrm{MBq} / \mathrm{mg}$ protein when Dose $\mathrm{A}_{\mathrm{A}}$ was $2 \mathrm{mg}$, and $\mathrm{C}_{\mathrm{IO}}$ was $3,700 \mathrm{MBq} / \mathrm{mg}$ protein when Dose ${ }_{\mathrm{A}}$ was $0.2 \mathrm{mg}$. $\mathrm{V}$ was $140 \mathrm{~mL}, \mathrm{~K}_{\mathrm{d}}$ was $10^{-8}$ $\mathrm{M}\left(\mathrm{k}_{\mathrm{AR}}=3 \times 10^{4} \mathrm{M}^{-1} \mathrm{~s}^{-1} ; \mathrm{k}_{-\mathrm{AR}}=3 \times 10^{-4} \mathrm{~s}^{-1}\right)$, and $\mathrm{t}_{1 / 2-\text { I }}$ was $193 \mathrm{~h}$.

initial $\mathrm{C}_{\mathrm{I} 0}$, and initial $\mathrm{C}_{\mathrm{R} 0}$. The therapeutic effect of the radioisotope-labeled antibody not only depends on its activity, which is the product of $\operatorname{Dose}_{\mathrm{A}}$ and the specific activity of the labeling isotope $\left(\mathrm{C}_{\mathrm{I}}\right)$, but also depends on the amount of tumor cell antigens $\left(\mathrm{C}_{\mathrm{R} 0}\right)$. For tumors with low antigen density, we may need to deliver a smaller amount of antibody but load the antibody with an isotope at a higher specific activity. To show the individual effect of Dose $\mathrm{A}_{\mathrm{A}}$ and $\mathrm{C}_{\mathrm{I} 0}$ for the same initial activity of $740 \mathrm{MBq}$ used in the phase I clinical trial (11), we used $2 \mathrm{mg}$ for Dose $_{\mathrm{A}}$ and $370 \mathrm{MBq} / \mathrm{mg}$ for $\mathrm{C}_{\mathrm{I} 0}(11)$ and $0.2 \mathrm{mg}$ for Dose $\mathrm{A}_{\mathrm{A}}$ and $3,700 \mathrm{MBq} / \mathrm{mg}$ for $\mathrm{C}_{\mathrm{I} 0}$ in Figure 5. For $\mathrm{C}_{\mathrm{R} 0}$, we estimated that it may vary from $10^{11}$ to $10^{14}$ antigens $/ \mathrm{mL}$ based on tumor types (antigens per cell) and coverage percentages on the surface of the CSF space (Supplemental Table 2). For the same activity of $740 \mathrm{MBq}$, a smaller Dose $_{\mathrm{A}}(0.2 \mathrm{mg})$ and larger $\mathrm{C}_{\mathrm{I} 0}(3,700 \mathrm{MBq} / \mathrm{mg})$, compared with a larger Dose ${ }_{\mathrm{A}}$ and smaller $\mathrm{C}_{\mathrm{I} 0}$, increased the
$\operatorname{AUC}\left(\mathrm{C}_{\mathrm{IAR}}\right)$ by approximately 2.9 -fold and $\mathrm{AUC}\left(\mathrm{C}_{\mathrm{IAR}}\right) /$ $\operatorname{AUC}\left(\mathrm{C}_{\mathrm{IA}}\right)$ by approximately 2.8 -fold for all the antigen concentrations. For the amount of tumor antigens considered, there are relatively more antibodies binding to the tumor cells

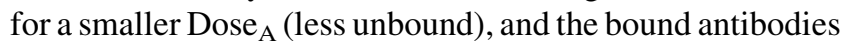
with higher $\mathrm{C}_{\mathrm{I} 0}$ would be more potent. This is also true for the same Dose $\mathrm{A}_{\mathrm{A}}$ and $\mathrm{C}_{\mathrm{I} 0}$ but for different $\mathrm{C}_{\mathrm{R} 0}$. The higher the tumor antigen concentration $\mathrm{C}_{\mathrm{R} 0}$, the more the bound antibodies $\mathrm{C}_{\mathrm{IAR}}$, the less the unbound $\mathrm{C}_{\mathrm{IA}}$, and the larger the $\operatorname{AUC}\left(\mathrm{C}_{\mathrm{IAR}}\right)$ and $\operatorname{AUC}\left(\mathrm{C}_{\mathrm{IAR}}\right) / \mathrm{AUC}\left(\mathrm{C}_{\mathrm{IA}}\right)$.

\section{Effect of Antibody Administration Schedule on Therapeutic Ratio}

Compared with the single-bolus administration described in the previous sections, continuous infusion and split dosing may improve the therapeutic ratio by maintaining a longer duration of constant drug concentration at therapeutic levels and avoiding high peak concentrations in the CSF to reduce toxicity. We used our model to predict the effect of administration patterns on $\operatorname{AUC}\left(C_{\text {IAR }}\right)$ and $\operatorname{AUC}\left(\mathrm{C}_{\mathrm{IAR}}\right) / \mathrm{AUC}\left(\mathrm{C}_{\mathrm{IA}}\right)$ in Figure 6. The total antibody amount Dose ${ }_{\mathrm{A}}$ of $2 \mathrm{mg}$ was the same for all 3 administration patterns. Figure $6 \mathrm{~A}$ compares the $\mathrm{C}_{\mathrm{IAR}}$-versus-time curves for a 1-dose administration and for continuous infusion for $12 \mathrm{~h}$ (infusion rate $\mathrm{INF}_{\mathrm{A}}=0.167$ $\mathrm{mg} / \mathrm{h}), 24\left(\mathrm{INF}_{\mathrm{A}}=0.083 \mathrm{mg} / \mathrm{h}\right)$ and $48 \mathrm{~h}\left(\mathrm{INF}_{\mathrm{A}}=0.042 \mathrm{mg} /\right.$ h). Continuous infusions have lower peak values for $\mathrm{C}_{\mathrm{IAR}}$ and flatter $\mathrm{C}_{\mathrm{IAR}}$-versus-time curves. The longer the infusion time, the lower the peak value and the longer the duration for a constant $\mathrm{C}_{\mathrm{IAR}}$. In addition, continuous infusion improved $\operatorname{AUC}\left(\mathrm{C}_{\mathrm{IAR}}\right)$ and $\mathrm{AUC}\left(\mathrm{C}_{\mathrm{IAR}}\right) / \mathrm{AUC}\left(\mathrm{C}_{\mathrm{IA}}\right)$. Figure $6 \mathrm{~B}$ shows that when the infusion time increased, $\mathrm{AUC}\left(\mathrm{C}_{\mathrm{IAR}}\right)$ increased and peaked at approximately $5 \mathrm{~d}$ but decreased at a longer infusion time. When the infusion time was 12,24 , and $48 \mathrm{~h}$, the improvement over single dosing on $\mathrm{AUC}\left(\mathrm{C}_{\mathrm{IAR}}\right)$ was 1.1-, 1.3-, and 1.5 -fold, correspondingly. The maximum improvement was 1.8-fold when the infusion time was $5 \mathrm{~d}$. Although there was a peak for $\mathrm{AUC}\left(\mathrm{C}_{\mathrm{IAR}}\right), \mathrm{AUC}\left(\mathrm{C}_{\mathrm{IAR}}\right) / \mathrm{AUC}\left(\mathrm{C}_{\mathrm{IA}}\right)$ increased with the infusion time until it plateaued at approximately $10 \mathrm{~d}$.
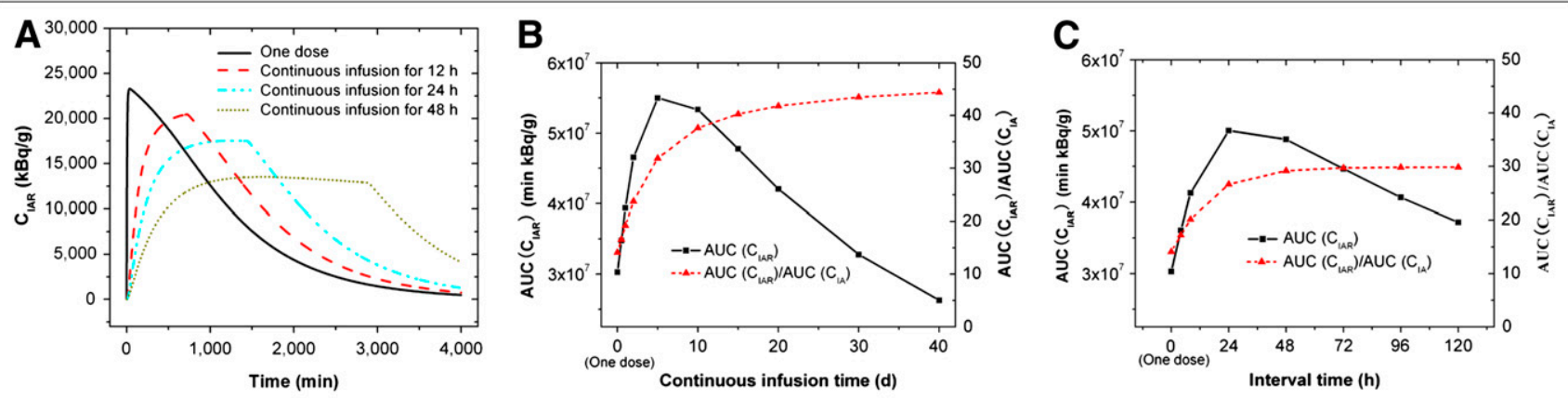

FIGURE 6. (A) $\mathrm{C}_{\mathrm{IAR}}$ as function of time in CSF compartment for single bolus administration and continuous infusion for 12, 24, and $48 \mathrm{~h}$, correspondingly. (B) $A U C\left(C_{I A R}\right)$ and $A U C\left(C_{I A R}\right) / A U C\left(C_{I A}\right)$ as function of infusion time for continuous infusion. (C) $A U C\left(C_{I A R}\right)$ and $\mathrm{AUC}\left(\mathrm{C}_{\mathrm{IAR}}\right) / \mathrm{AUC}\left(\mathrm{C}_{\mathrm{IA}}\right)$ as function of time interval between dosing for 4 injections. Total dose of 2-mg antibody is same for different administration schedules. $V$ was $140 \mathrm{~mL}, \mathrm{~K}_{\mathrm{d}}$ was $10^{-8} \mathrm{M}\left(\mathrm{k}_{\mathrm{AR}}=3 \times 10^{4} \mathrm{M}^{-1} \mathrm{~s}^{-1} ; \mathrm{k}_{-\mathrm{AR}}=3 \times 10^{-4} \mathrm{~s}^{-1}\right)$, tumor $\mathrm{C}_{\mathrm{RO}}$ was $5.73 \times 10^{14}$ antigens $/ \mathrm{mL}, \mathrm{C}_{10}$ was $370 \mathrm{MBq} / \mathrm{mg}$, and $\mathrm{t}_{1 / 2-1}$ was $193 \mathrm{~h}$. 
Split dosing achieved improvements similar to those achieved with continuous infusion. Figure $6 \mathrm{C}$ shows the effect of the time interval between dosing for 4 injections on $\operatorname{AUC}\left(\mathrm{C}_{\mathrm{IAR}}\right)$ and $\mathrm{AUC}\left(\mathrm{C}_{\mathrm{IAR}}\right) / \mathrm{AUC}\left(\mathrm{C}_{\mathrm{IA}}\right)$. The amount of antibody for each split administration was $0.5 \mathrm{mg}$ with the total of $2 \mathrm{mg}$, the same as for single-bolus administration (1 dose). When the time was $4 \mathrm{~h}$ (administering $0.5 \mathrm{mg}$ every $4 \mathrm{~h}$ for 4 times) and $8 \mathrm{~h}$ (administering $0.5 \mathrm{mg}$ every $8 \mathrm{~h}$ for 4 times), the improvement over single dosing on $\mathrm{AUC}\left(\mathrm{C}_{\mathrm{IAR}}\right)$ was 1.2- and 1.4-fold, respectively. The maximum improvement was 1.7fold when the time was $24 \mathrm{~h}$. The longer than 24 -h time would reduce the improvement. Although there was a peak for $\operatorname{AUC}\left(\mathrm{C}_{\mathrm{IAR}}\right), \operatorname{AUC}\left(\mathrm{C}_{\mathrm{IAR}}\right) / \mathrm{AUC}\left(\mathrm{C}_{\mathrm{IA}}\right)$ increased with the time until it plateaued at approximately $24 \mathrm{~h}$.

\section{Effect of $\mathrm{t}_{1 / 2-1}$ on Therapeutic Ratio}

In addition to ${ }^{131} \mathrm{I}\left(\mathrm{t}_{1 / 2-\mathrm{I}}=193 \mathrm{~h}\right)$, many other isotopes with various half-lives can be used in radioimmunotherapy: ${ }^{225} \mathrm{Ac}$ $\left(\mathrm{t}_{1 / 2-\mathrm{I}}=240 \mathrm{~h}\right),{ }^{172} \mathrm{Lu}\left(\mathrm{t}_{1 / 2-\mathrm{I}}=161 \mathrm{~h}\right),{ }^{90} \mathrm{Y}\left(\mathrm{t}_{1 / 2-\mathrm{I}}=64 \mathrm{~h}\right),{ }^{211} \mathrm{At}$ $\left(\mathrm{t}_{1 / 2-\mathrm{I}}=7.2 \mathrm{~h}\right)$, and ${ }^{213} \mathrm{Bi}\left(\mathrm{t}_{1 / 2-\mathrm{I}}=0.77 \mathrm{~h}\right)(14-16)$. Increasing $t_{1 / 2-I}$ delays the decay of the radioactivity of bound antibodies $\left(\mathrm{C}_{\mathrm{IAR}}\right)$ and would increase the therapeutic ratio. We used our model to predict the effect of $t_{1 / 2-I}$ on the $\operatorname{AUC}\left(\mathrm{C}_{\mathrm{IAR}}\right)$ and $\operatorname{AUC}\left(\mathrm{C}_{\mathrm{IAR}}\right) / \mathrm{AUC}\left(\mathrm{C}_{\mathrm{IA}}\right)$ (Fig. 7). For 3F8 (anti-GD2) with a $\mathrm{K}_{\mathrm{d}}$ of $10^{-8} \mathrm{M}\left(\mathrm{k}_{\mathrm{AR}}=3 \times 10^{4} \mathrm{M}^{-1} \mathrm{~s}^{-1}\right.$ and $\mathrm{k}_{-\mathrm{AR}}=3 \times 10^{-4}$ $\mathrm{s}^{-1}$ ) used in a study by Xu et al. (33), Figure 7A shows that increasing $\mathrm{t}_{1 / 2-\mathrm{I}}$ from 0.77 to $7.2 \mathrm{~h}$ greatly increased the $\operatorname{AUC}\left(\mathrm{C}_{\mathrm{IAR}}\right)$ by 7.8 -fold and $\mathrm{AUC}\left(\mathrm{C}_{\mathrm{IAR}}\right) / \mathrm{AUC}\left(\mathrm{C}_{\mathrm{IA}}\right)$ by $1.7-$ fold; increasing $\mathrm{t}_{1 / 2-\mathrm{I}}$ from 7.2 to $64 \mathrm{~h}$ moderately increased the $\mathrm{AUC}\left(\mathrm{C}_{\mathrm{IAR}}\right)$ by $2.4-$ fold and $\mathrm{AUC}\left(\mathrm{C}_{\mathrm{IAR}}\right) / \mathrm{AUC}\left(\mathrm{C}_{\mathrm{IA}}\right)$ by 1.5 -fold. Increasing $\mathrm{t}_{1 / 2-\mathrm{I}}$ further above $64 \mathrm{~h}$ improved only slightly the $\operatorname{AUC}\left(\mathrm{C}_{\mathrm{IAR}}\right)(<10 \%)$ and $\mathrm{AUC}\left(\mathrm{C}_{\mathrm{IAR}}\right) / \mathrm{AUC}\left(\mathrm{C}_{\mathrm{IA}}\right)$ $(<5 \%)$. Interestingly, when the affinity $\mathrm{K}_{\mathrm{d}}$ was increased to $10^{-10} \mathrm{M}$, the $\mathrm{t}_{1 / 2-\mathrm{I}}$ effect was different from the effect for a
$10^{-8} \mathrm{M}$ increase (Fig. 7B). Increasing $\mathrm{t}_{1 / 2-\mathrm{I}}$ from 0.77 to $7.2 \mathrm{~h}$ and from 7.2 to $64 \mathrm{~h}$ greatly increased $\mathrm{AUC}\left(\mathrm{C}_{\mathrm{IAR}}\right)$ by $9.3-$ and 6.9-fold, respectively, and $\operatorname{AUC}\left(\mathrm{C}_{\mathrm{IAR}}\right) / \mathrm{AUC}\left(\mathrm{C}_{\mathrm{IA}}\right)$ by 2.1 and 4.3-fold, respectively. Increasing $\mathrm{t}_{1 / 2-\mathrm{I}}$ from 64 to $161 \mathrm{~h}$ moderately increased the $\mathrm{AUC}\left(\mathrm{C}_{\mathrm{IAR}}\right)$ by 1.9 -fold and $\mathrm{AUC}$ $\left(\mathrm{C}_{\text {IAR }}\right) / A U C\left(\mathrm{C}_{\mathrm{IA}}\right)$ by 1.8 -fold; further increasing $\mathrm{t}_{1 / 2-\mathrm{I}}$ from 161 to $193 \mathrm{~h}$ and from 193 to $240 \mathrm{~h}$ improved AUC(C $\left.\mathrm{C}_{\text {IAR }}\right)$ and $\operatorname{AUC}\left(\mathrm{C}_{\mathrm{IAR}}\right) / \mathrm{AUC}\left(\mathrm{C}_{\mathrm{IA}}\right)$ by about $10 \%$ for each increment. However, increasing $\mathrm{t}_{1 / 2-\mathrm{I}}$ from 240 to $1,000 \mathrm{~h}$ significantly increased $\mathrm{AUC}\left(\mathrm{C}_{\mathrm{IAR}}\right)$ and $\mathrm{AUC}\left(\mathrm{C}_{\mathrm{IAR}}\right) / \mathrm{AUC}\left(\mathrm{C}_{\mathrm{IA}}\right)$ by $90 \%$ and $80 \%$, respectively. Increasing the affinity from $10^{-8}$ to $10^{-10} \mathrm{M}$ would allow stronger and longer binding of antibody to the antigen (larger $\mathrm{C}_{\mathrm{AR}}$ and smaller $\mathrm{C}_{\mathrm{A}}$ ), and the much longer $t_{1 / 2-I}$ of the isotope would greatly delay the decrease in $\mathrm{C}_{\mathrm{I}}$; therefore, we have the larger $\mathrm{C}_{\mathrm{IAR}}$ and smaller $\mathrm{C}_{\mathrm{IA}}$ at each time point.

To examine the individual effect of binding or dissociation rate constants $\mathrm{k}_{\mathrm{AR}}$ and $\mathrm{k}_{-\mathrm{AR}}$ for the same affinity $\mathrm{K}_{\mathrm{d}}$, we predict the $\mathrm{AUC}\left(\mathrm{C}_{\mathrm{IAR}}\right)$ (normalized with the value at the highest affinity) as a function of $\mathrm{k}_{\mathrm{AR}}$ and $\mathrm{k}_{-\mathrm{AR}}$ in Figure $7 \mathrm{C}$ for the isotope with the shortest $\mathrm{t}_{1 / 2-\mathrm{I}}$ of $0.77 \mathrm{~h}$ and in Figure 7D for the isotope with the longest available $t_{1 / 2-I}$ of $240 \mathrm{~h}$. The arrow with the quantity (slope) indicates the increase in $\operatorname{AUC}\left(\mathrm{C}_{\mathrm{IAR}}\right)$ per unit increase in the equivalent affinity (including the individual effect of $\mathrm{k}_{\mathrm{AR}}$ and $\mathrm{k}_{-\mathrm{AR}}$ ) when $\left(\mathrm{k}_{\mathrm{AR}}, \mathrm{k}_{-\mathrm{AR}}\right)$ increases from one set of values to another. The larger the slope, the larger the improvement in $\operatorname{AUC}\left(\mathrm{C}_{\mathrm{IAR}}\right)$. For example, for a $t_{1 / 2-I}$ of $0.77 \mathrm{~h}$, the largest improvement in $\operatorname{AUC}\left(\mathrm{C}_{\mathrm{IAR}}\right)$ was when $\left(\mathrm{k}_{\mathrm{AR}}, \mathrm{k}_{-\mathrm{AR}}\right)$ increased from $\left(3 \times 10^{3}\right.$ $\left.\mathrm{M}^{-1} \mathrm{~s}^{-1}, 3 \times 10^{-3} \mathrm{~s}^{-1}\right)$ to $\left(3 \times 10^{4} \mathrm{M}^{-1} \mathrm{~s}^{-1}, 3 \times 10^{-4} \mathrm{~s}^{-1}\right)$ because it had the largest slope of 0.53 in Figure 7C. Further increase from $\left(3 \times 10^{4} \mathrm{M}^{-1} \mathrm{~s}^{-1}, 3 \times 10^{-4} \mathrm{~s}^{-1}\right)$ to $\left(3 \times 10^{5}\right.$ $\left.\mathrm{M}^{-1} \mathrm{~s}^{-1}, 3 \times 10^{-5} \mathrm{~s}^{-1}\right)$ did not gain much improvement - the slope was only 0.13 - despite a substantial effort to increase
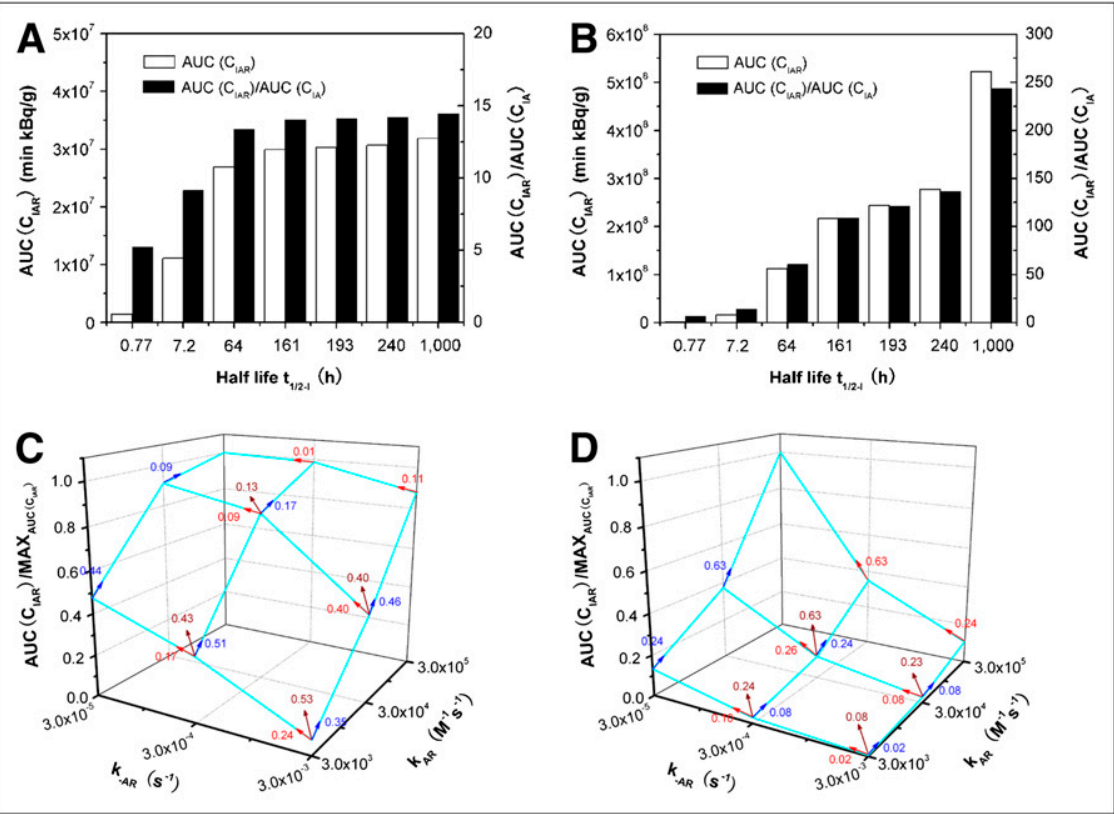

FIGURE 7. AUC $\left(\mathrm{C}_{\mathrm{IAR}}\right)$ and $\mathrm{AUC}\left(\mathrm{C}_{\mathrm{IAR}}\right) /$ $A \cup C\left(C_{I A}\right)$ as function of $t_{1 / 2-I}$ when $K_{d}=$ $10^{-8} \mathrm{M}(\mathrm{A})$ and $\mathrm{K}_{\mathrm{d}}=10^{-10} \mathrm{M}(\mathrm{B})$. Normalized $A \cup C\left(\mathrm{C}_{\mathrm{IAR}}\right)$ as function of $\mathrm{k}_{\mathrm{AR}}$ and $\mathrm{k}_{-\mathrm{AR}}$ rate constants when $\mathrm{t}_{1 / 2-1}=$ 0.77 (C) and $t_{1 / 2-I}=240.0 \mathrm{~h}$ (D). $\mathrm{K}_{\mathrm{d}}$ equaled $\frac{k_{-A R}}{k_{A R}}$, and $V$ was $140 \mathrm{~mL}$, tumor $\mathrm{C}_{\mathrm{RO}}$ was $5.73 \times 10^{14}$ antigens $/ \mathrm{mL}$, Dose $_{\mathrm{A}}$ was $2 \mathrm{mg}$, and $\mathrm{C}_{\mathrm{IO}}$ was 370 $\mathrm{MBq} / \mathrm{mg}$. 
$\mathrm{K}_{\mathrm{d}}$ from $10^{-8}$ to $10^{-10} \mathrm{M}$. In contrast, for a $\mathrm{t}_{1 / 2-\mathrm{I}}$ of $240 \mathrm{~h}$, the most improvement in $\mathrm{AUC}\left(\mathrm{C}_{\mathrm{IAR}}\right)$ was when $\left(\mathrm{k}_{\mathrm{AR}}, \mathrm{k}_{-\mathrm{AR}}\right)$ increased from $\left(3 \times 10^{4} \mathrm{M}^{-1} \mathrm{~s}^{-1}, 3 \times 10^{-4} \mathrm{~s}^{-1}\right)$ to $\left(3 \times 10^{5}\right.$ $\mathrm{M}^{-1} \mathrm{~s}^{-1}, 3 \times 10^{-5} \mathrm{~s}^{-1}$ ) because the slope was 0.63 , the largest among others. So, it is worthwhile to increase $\mathrm{K}_{\mathrm{d}}$ from $10^{-8}$ to $10^{-10} \mathrm{M}$ for the antibody with a $\mathrm{t}_{1 / 2-\mathrm{I}}$ of $240 \mathrm{~h}$.

For a $t_{1 / 2-I}$ of $0.77 \mathrm{~h}$, the plot of $\operatorname{AUC}\left(\mathrm{C}_{\text {IAR }}\right)$ is not symmetric about the $\left(\mathrm{k}_{\mathrm{AR}}, \mathrm{k}_{-\mathrm{AR}}\right)$ axes. The increase in $\mathrm{k}_{\mathrm{AR}}$ led to more improvement in $\mathrm{AUC}\left(\mathrm{C}_{\mathrm{IAR}}\right)$ than did the decrease in $\mathrm{k}_{-\mathrm{AR}}$ for the same $\mathrm{K}_{\mathrm{d}}$. For example, if $\left(\mathrm{k}_{\mathrm{AR}}, \mathrm{k}_{-\mathrm{AR}}\right)$ increased from $\left(3 \times 10^{3} \mathrm{M}^{-1} \mathrm{~s}^{-1}, 3 \times 10^{-3} \mathrm{~s}^{-1}\right)$ to $\left(3 \times 10^{5}\right.$ $\mathrm{M}^{-1} \mathrm{~s}^{-1}, 3 \times 10^{-3} \mathrm{~s}^{-1}$ ) along the $\mathrm{k}_{\mathrm{AR}}$ axis, the improvement in $\operatorname{AUC}\left(\mathrm{C}_{\mathrm{IAR}}\right)$ was 12.5 -fold, whereas from $\left(3 \times 10^{3} \mathrm{M}^{-1} \mathrm{~s}^{-1}\right.$, $\left.3 \times 10^{-3} \mathrm{~s}^{-1}\right)$ to $\left(3 \times 10^{3} \mathrm{M}^{-1} \mathrm{~s}^{-1}, 3 \times 10^{-5} \mathrm{~s}^{-1}\right)$ along the $\mathrm{k}_{-\mathrm{AR}}$ axis, the improvement was only 6.7 -fold. For both cases, $\mathrm{K}_{\mathrm{d}}$ was from $10^{-6} \mathrm{M}$ to $10^{-8} \mathrm{M}$. However, this asymmetry was lost when the $\mathrm{t}_{1 / 2 \text {-I }}$ was $240 \mathrm{~h}$. The decrease in $\mathrm{k}_{-\mathrm{AR}}$ instead of the increase in $\mathrm{k}_{\mathrm{AR}}$ could bring about slightly higher gain in $\operatorname{AUC}\left(\mathrm{C}_{\mathrm{IAR}}\right)$, about $20 \%$ when $\mathrm{K}_{\mathrm{d}}$ is from $10^{-6} \mathrm{M}$ to $10^{-8} \mathrm{M}$.

\section{DISCUSSION}

The validity of any model rests on how well the data fit. We passed that test by showing near-perfect agreement between model predictions and patient pharmacokinetic data obtained in the phase I clinical trial (the correlation coefficients were greater than 0.99). Several of the predictions from the model were intuitive, although not necessarily quantitative, and some of the predictions were unexpected.

We expected that increasing the antibody affinity to the antigen $\left(\mathrm{K}_{\mathrm{d}}\right)$ would enhance the $\mathrm{AUC}\left(\mathrm{C}_{\mathrm{IAR}}\right)$. With a quantitative model, we now can predict how much enhancement to expect with each increment of $\mathrm{K}_{\mathrm{d}}$ and what the respective contribution is from $\mathrm{k}_{\mathrm{AR}}$ or $\mathrm{k}_{-\mathrm{AR}}$. When the affinity $\mathrm{K}_{\mathrm{d}}$ is improved from $10^{-6}$ to $10^{-7} \mathrm{M}$, the enhancement in $\mathrm{AUC}\left(\mathrm{C}_{\mathrm{IAR}}\right)$ is 7.6-fold. This enhancement is reduced to 4.8-, 2.7-, 2.4-, 1.5-, and 1.1-fold, respectively, as $\mathrm{K}_{\mathrm{d}}$ is decreased from $10^{-7}$ to $10^{-8} \mathrm{M}, 10^{-8}$ to $10^{-9} \mathrm{M}, 10^{-9}$ to $10^{-10} \mathrm{M}, 10^{-10}$ to $10^{-11}$ $\mathrm{M}$, and $10^{-11}$ to $10^{-12} \mathrm{M}$. These predictions suggest that increasing the affinity up to $10^{-10} \mathrm{M}$ should bring about the optimal enhancement in $\mathrm{AUC}\left(\mathrm{C}_{\mathrm{IAR}}\right)$. Further increases in affinity have diminishing returns, especially when one considers the technical difficulty in developing ligands with $\mathrm{K}_{\mathrm{d}}$ beyond $10^{-10} \mathrm{M}$. Somewhat unexpected was the prediction that for the same increase in the affinity, increasing $\mathrm{k}_{\mathrm{AR}}$ provides much more benefit for an isotope with a short $\mathrm{t}_{1 / 2-\mathrm{I}}$ $(0.77 \mathrm{~h})$; but when the $\mathrm{t}_{1 / 2-\mathrm{I}}$ increases to $240 \mathrm{~h}$, decreasing $\mathrm{k}_{-\mathrm{AR}}$ would bring slightly more enhancement in $\mathrm{AUC}\left(\mathrm{C}_{\mathrm{IAR}}\right)$.

The biologic half-life of ${ }^{131} \mathrm{I}$ loaded to the antibody in the CSF was much faster $(3-12.9 \mathrm{~h})(11)$ than its physical $\mathrm{t}_{1 / 2-\mathrm{I}}$ of $193 \mathrm{~h}$. The half-life of ${ }^{131} \mathrm{I}-3 \mathrm{~F} 8$ in the CSF predicted by our model was 5.2 and $6.7 \mathrm{~h}$, respectively, for 2 representative patients. The strong agreement between the model prediction and the measured patient data suggests that the rapid decrease in the activity of the $\mathrm{CSF}^{131} \mathrm{I}-3 \mathrm{~F} 8$ is mainly due to the clearance from the $\mathrm{CL}_{\mathrm{CSF}}$, an assumption we made in our model. If we reduce the $\mathrm{CL}_{\mathrm{CSF}}$ by acetazolamide and furosemide (36), we would increase $\mathrm{AUC}\left(\mathrm{C}_{\mathrm{IAR}}\right)$. However, reducing $\mathrm{CL}_{\mathrm{CSF}}$ would also reduce $\mathrm{AUC}\left(\mathrm{C}_{\mathrm{IAR}}\right)$ / $\operatorname{AUC}\left(\mathrm{C}_{\mathrm{IA}}\right)$ but at a much slower rate if $\mathrm{CL}_{\mathrm{CSF}}$ was above 3 $\mathrm{mL} / \mathrm{h}$. For the CSF delivery of ${ }^{131} \mathrm{I}-3 \mathrm{~F} 8, \mathrm{CL}_{\mathrm{CSF}}$ of $3 \mathrm{~mL} / \mathrm{h}$ was an optimal condition. This quantitative conclusion was also unexpected because common sense may suggest that zero CSF flow should be ideal after the antibody injection. For other compartments not through the CSF, such as intraperitoneal administration, a new model needs to be developed to include clearances through peritoneal fluid circulation and excretion through the kidney and liver.

In addition to the antibody clearance from CSF and the half-life of the isotope loaded onto antibodies, the strength (or half-life) of the bonding between the isotope and antibody (iodine bond or metal chelation) may be just as important. Halogen bonds (e.g., iodine or astatine) are broken during systemic circulation (e.g., dehalogenation by the liver) but less so in the intrathecal space. More importantly, unlike serum, CSF does not have the enzymes and proteins to destabilize these bonds; therefore, we expect radioconjugate to be more stable in the CSF versus the blood compartment. As predicted by our model, for the same amount of isotope (total activity) $\mathrm{C}_{\mathrm{IA} 0}\left(\right.$ Dose $_{\mathrm{A}} \times \mathrm{C}_{\mathrm{I} 0}$ ), the smaller the antibody dose Dose $_{\mathrm{A}}$, the higher the specific activity $\mathrm{C}_{\mathrm{IO}}$, the larger the $\mathrm{AUC}\left(\mathrm{C}_{\mathrm{IAR}}\right)$, and more radioimmunotherapy efficacy. However, it is difficult to produce high-specific-activity $\mathrm{C}_{\mathrm{I} O}$ before destroying the immunoreactivity of mAb. Using a more potent radioisotope (e.g., $\alpha$-emitter ${ }^{225} \mathrm{Ac}$ ) may be an alternative.

Although continuous infusion and split dosing, compared with a single bolus administration, would improve the radioimmunotherapy efficacy by up to 1.8 - and 1.7 -fold in $\operatorname{AUC}\left(\mathrm{C}_{\mathrm{IAR}}\right)$ it may not be clinically convenient. The maximum enhancement of 1.8- or 1.7-fold requires a 5-d continuous infusion or 4 injections given every $24 \mathrm{~h}$ over $4 \mathrm{~d}$.

Parameters in Equation A5 in the supplemental materials (i.e., $\mathrm{CL}_{\mathrm{CSF}} / \mathrm{V}, \mathrm{S} / \mathrm{V}, \mathrm{C}_{\mathrm{IA} 0}$, and $\mathrm{C}_{\mathrm{R} 0}$ ) are species-specific, and a different set of values will need to be used if one were to apply these equations to nonhuman primates or small rodents. However, predictions from our model should be valid irrespective of species. Before translating these predictions to patient clinical trials, they can be further tested using these preclinical animal systems.

\section{CONCLUSION}

The strong agreement between model predictions and patient pharmacokinetic data obtained from patients in a clinical trial validates the assumptions and simplifications in our model. Using this model to optimize therapeutic ratio, we made predictions on critical kinetic and transport parameters, which will require further clinical validation. We believe that this model can provide an efficient and cost-effective approach in improving the clinical efficacy in this emerging treatment modality. 


\section{ACKNOWLEDGMENTS}

We thank Dr. John Humm and Dr. Larson, Nuclear Medicine, Department of Radiology, and Dr. Kim Kramer, Department of Pediatrics, for their expert input regarding patients treated with intra-Ommaya ${ }^{131} \mathrm{I} 3 \mathrm{~F} 8$. This work was supported in part by grants from the National Institutes of Health (CA106450 and P20 CA118861-01), Robert Steel Foundation, Hope Street Kids, William H. Goodwin and Alice Goodwin, the Commonwealth Foundation for Cancer Research, and the Experimental Research Center of MSKCC. 3F8 was licensed by Memorial Sloan-Kettering Cancer Center to United Therapeutics, Inc., Silver Spring, MD.

\section{REFERENCES}

1. Bruno MK, Raizer J. Leptomeningeal metastases from solid tumors (meningeal carcinomatosis). Cancer Treat Res. 2005;125:31-52.

2. Gleissner B, Chamberlain MC. Neoplastic meningitis. Lancet Neurol. 2006; 5:443-452.

3. Grossman SA, Spence A. NCCN clinical practice guidelines for carcinomatous/ lymphotous meningitis. Oncology. 1999;13:144-152.

4. Balm M, Hammack J. Leptomeningeal carcinomatosis: presenting features and prognostic factors. Arch Neurol. 1996;53:626-632.

5. Wasserstrom WR, Glass JP, Posner JB. Diagnosis and treatment of leptomeningeal metastases from solid tumors: experience with 90 patients. Cancer. 1982;49:759-772.

6. Chamberlain MC. Neoplastic meningitis. J Clin Oncol. 2005;23:3605-3613.

7. Freilich RJ, Krol G, DeAngelis LM. Neuroimaging and cerebrospinal fluid cytology in the diagnosis of leptomeningeal metastasis. Ann Neurol. 1995;38: 51-57.

8. Smith DB, Howell A, Harris M, Bramwell VH, Sellwood RA. Carcinomatous meningitis associated with infiltrating lobular carcinoma of the breast. Eur J Surg Oncol. 1985;11:33-36.

9. Posner JB. Neurologic Complications of Cancer. Comtemporary Neurology Series, Vol 45. Philadelphia, PA: F.A. Davis Company; 1995.

10. Kramer K, Kushner B, Heller G, Cheung NK. Neuroblastoma metastatic to the central nervous system: the Memorial Sloan-Kettering Cancer Center Experience and a literature review. Cancer. 2001;91:1510-1519.

11. Kramer K, Humm JL, Souweidane MM, et al. Phase I study of targeted radioimmunotherapy for leptomeningeal cancers using intra-Ommaya 131-I-3F8. J Clin Oncol. 2007;25:5465-5470.

12. Guyton AC, Hall JE. Textbook of Medical Physiology. 10th ed. Philadelphia, PA: Saunders; 2000.

13. Smith DE, Johanson CE, Keep RF. Peptide and peptide analog transport systems at the blood-CSF barrier. Adv Drug Deliv Rev. 2004;56:1765-1791.

14. McDevitt MR, Ma D, Lai LT, et al. Tumor therapy with targeted atomic nanogenerators. Science. 2001;294:1537-1540.

15. Miederer M, McDevitt MR, Sgouros G, Kramer K, Cheung NK, Scheinberg DA. Pharmacokinetics, dosimetry, and toxicity of the targetable atomic generator, ${ }^{225}$ Ac-HuM195, in nonhuman primates. J Nucl Med. 2004;45:129-137.

16. Humm JL. Dosimetric aspects of radiolabeled antibodies for tumor therapy. J Nucl Med. 1986;27:1490-1497.

17. Baxter LT, Jain RK. Transport of fluid and macromolecules in tumors. I. Role of interstitial pressure and convection. Microvasc Res. 1989;37:77-104.
18. Eger RR, Covell DG, Carrasquillo JA, et al. Kinetic model for the biodistribution of an ${ }^{111}$ In-labeled monoclonal antibody in humans. Cancer Res. 1987;47:33283336.

19. Thierens HM, Monsieurs MA, Brans B, Van Driessche T, Christiaens I, Dierckx RA. Dosimetry from organ to cellular dimensions. Comput Med Imaging Graph. 2001;25:187-193.

20. Moseley RP, Davies AG, Richardson RB, et al. Intrathecal administration of 131I-radiolabelled $\mathrm{MoAb}$ as a treatment for neoplastic meningitis. $\mathrm{Br} \mathrm{J}$ Cancer. 1990;62:637-642.

21. Kemshead JT, Papanastassiou V, Coakham HB, Pizer BL. Monoclonal antibodies in the treatment of central nervous system malignancies. Eur J Cancer. 1992; 28:511-513.

22. Brown MT, Coleman RE, Friedman AH, et al. Intrathecal ${ }^{131} \mathrm{I}$-labeled antitenascin monoclonal antibody $81 \mathrm{C} 6$ treatment of patients with leptomeningeal neoplasms or primary brain tumor resection cavities with subarachnoid communication: phase I trial results. Clin Cancer Res. 1996;2:963-972.

23. Riva P, Franceschi G, Frattarelli M, et al. Loco-regional radioimmunotherapy of high-grade malignant gliomas using specific monoclonal antibodies labeled with ${ }^{90}$ Y: a phase I study. Clin Cancer Res. 1999;5:3275s-3280s.

24. Bigner DD, Brown MT, Friedman AH, et al. Iodine-131-labeled antitenascin monoclonal antibody 81C6 treatment of patients with recurrent malignant gliomas: phase I trial results. J Clin Oncol. 1998;16:2202-2212.

25. Reardon DA, Zalutsky MR, Akabani G, et al. A pilot study: ${ }^{131} \mathrm{I}$-antitenascin monoclonal antibody $81 \mathrm{c} 6$ to deliver a $44-\mathrm{Gy}$ resection cavity boost. NeuroOncol. 2008;10:182-189.

26. Goldenberg DM, Sharkey RM, Paganelli G, Barbet J, Chatal JF. Antibody pretargeting advances cancer radioimmunodetection and radioimmunotherapy. J Clin Oncol. 2006;24:823-834.

27. Blasberg RG, Patlak CS, Shapiro WR. Distribution of methotrexate in the cerebrospinal fluid and brain after intraventricular administration. Cancer Treat Rep. 1977;61:633-641.

28. Fenstermacher JD, Blasberg RG, Patlak CS. Methods for quantifying the transport of drugs across brain barrier systems. Pharmacol Ther. 1981;14:217-248.

29. Yeh SD, Larson SM, Burch L, et al. Radioimmunodetection of neuroblastoma with iodine-131-3F8: correlation with biopsy, iodine-131-metaiodobenzylguanidine and standard diagnostic modalities. J Nucl Med. 1991;32:769-776.

30. Silverberg GD, Heit G, Huhn S, et al. The cerebrospinal fluid production rate is reduced in dementia of the Alzheimer's type. Neurology. 2001;57:1763-1766.

31. Barta P, Dazzan P. Hemispheric surface area: sex, laterality and age effects. Cereb Cortex. 2003;13:364-370.

32. Errera M, Forssberg A. Mechanisms in Radiobiology. 1st ed. New York, NY: Academic Press; 1960

33. $\mathrm{Xu} \mathrm{H}, \mathrm{Hu}$ J, Cheung NV. Induction of tumor cell death by anti-GD2 monoclonal antibodies $(\mathrm{MoAb})$ : requirement of antibody $\mathrm{Fc}$ and a long residence time (slow $\mathrm{k}_{\text {off }}$ ) [abstract]. J Clin Oncol. 2007;25(June 20 suppl):13507.

34. Cheung NK, Modak S, Lin Y, et al. Single-chain Fv-streptavidin substantially improved therapeutic index in multistep targeting directed at disialoganglioside GD2. J Nucl Med. 2004;45:867-877.

35. Murphy VA, Johanson CE. Acidosis, acetazolamide, and amiloride: effects on ${ }^{22} \mathrm{Na}$ transfer across the blood-brain and blood-CSF barriers. J Neurochem. 1989;52:1058-1063.

36. Johanson CE. Differential effects of acetazolamide, benzolamide and systemic acidosis on hydrogen and bicarbonate gradients across the apical and basolateral membranes of the choroid plexus. J Pharmacol Exp Ther. 1984;231:>502-511.

37. Knuckey NW, Preston J, Palm D, Epstein MH, Johanson C. Hydrocephalus decreases chloride efflux from the choroid plexus epithelium. Brain Res. 1993;618:313-317.

38. Hakvoort A, Johanson CE. Growth factor modulation of CSF formation by isolated choroid plexus: FGF-2 vs. TGF-beta1. Eur J Pediatr Surg. 2000;10:44-46. 